\title{
Life Without Father: The Role of the Paternal in the Opening Chapters of Huckleberry Finn
}

\author{
HARRY G. SEGAL
}

Critics have argued for generations about the failure of the ending of Huckleberry Finn. Ernest Hemingway began the debate by characterizing the escapades at Silas Phelps' farm as "cheating"; his statement was soon followed by rhetorical volleys between Eliot, Trilling, Marx, and others whose writings, taken together, form a miniature canon all their own. ${ }^{1}$ While the ending has been variously defended on formal, political, aesthetic, and moral grounds, the very presence of a debate sustained for more than sixty years bears witness to the "problem" of those closing chapters. Perhaps the most simple, and ultimately unanswerable, criticism

Harry G. Segal is Assistant Professor of Clinical Psychology, Department of Psychology, Hobart \& William Smith Colleges, Geneva, New York 14456-3397, U.S.A.

1 The series of essays about the ending of Huckleberry Finn have been referenced as a group many times and may be found collected in several critical anthologies as well as in an appendix to Norton's annotated edition of the novel. The following footnote is excerpted from "Mark Twain, 'Realism,' and Huckleberry Finn" in Louis Budd, ed., New Essays on Huckeleberry Finn (Cambridge: Cambridge University Press, 1985):

The locus classicus of the stand-off between proponents of the humorous and serious Twains is the famous debate about the ending ... beginning with Ernest Hemingway's declaration that "if you read it you must stop where the Nigger Jim is stolen from the boys. This is the real end. The rest is just cheating" (Green Hills of Africa [New York: Scribner's, 1935], p. 22). Leo Marx argues that the burlesque ending betrays the serious implications of the novel in "Mr. Eliot, Mr. Trilling and Huckleberry Finn," American Scholar 22 (1953):423-40. His targets, on the basis of equally serious readings of the novel, defend the ending. See Lionel Trilling, "Huckleberry Finn" in The Liberal Imagination (New York: Scribner's, 1950), reprinted in Claude M. Simpson, ed. Twentieth Century Interpretations of Huckleberry Finn (Englewood Cliffs, N.J.): Prentice-Hall, 1968), pp. 107-8. James Cox, to continue the available permutations and combinations, defends the ending as part of his attack on serious readings of the book. See Mark Twain: The Fate of Humor (Princeton, N.J. : Princeton University Press, 1966), pp. 175-82...f for a general discussion of this debate, see John Reichert, Making Sense of Literature (Chicago: University of Chicago Press, 1977), pp. 191-203.

Journal of American Studies, 27 (1993), I, 19-33. (C) 1993 Cambridge University Press 
of the ending is that the characters have grown inexplicably youngerthat is, they appear to behave in ways which disregard or "undo" their earlier, more maturing experiences. It seems inconceivable that Huck would go along so easily with Tom's Count of Monte Cristo escapades after witnessing the Grangerfords' feud, just as Jim's childlike acquiescence to the escape plan cannot be reconciled with the wisdom and dignity he had earlier shown as Huck's surrogate parent. Despite the ingenuity of even the most brilliant supporters, no reading can provide the characters in the closing chapters with those psychological qualities they so palpably lack; instead, supporters are left in the more awkward position of arguing that the failure of the ending constitutes an ironic success.

This essay is not intended as a late entry into the long-standing debate. Rather than justifying or attacking the constricted conventionality of the novel's ending, what follows is an explanation of why it occurs. I begin with this observation: the superficiality of the book's close does not abruptly follow an otherwise serious novel. Critics have been so distracted by the unsatisfying ending that they have failed to note that Huckleberry Finn begins with a series of evocative, dreamlike chapters which begins to give way to Twain's more conventional parodies of Southern society long before Huck is taken for Tom by Aunt Polly. This shift starts with the death of the Grangerfords and the arrival of the King and the Duke from there the narrative unevenly divests itself of emotional resonance before culminating in the flat, parodic tone of the final chapters. In contrast, the most powerful passages of the novel may be found in the opening sequences where Huck awaits the arrival of his father, escapes him, and rushes off in a blaze of ambivalence with his alternate father, Jim. I believe the one is an avoidant answer to the other; that is, the difficulties of the novel's ending may be explained as a reaction to the depth of its beginning.

The novel's opening invokes a broad range of formal and psychological issues by its juxtaposition of character and novelist, fiction and reality, and ultimately, that of father and son. Huck's competitive relationship with "Mark Twain," his response to the sighting of pap's "corpse," and his flight to Judge Thatcher and Jim after recognizing pap's footprints, may be read together as a depiction of a son's turbulent struggle against intimacy with a threatening father. I will argue that the process of writing those beginning chapters, often interrupted by writing blocks, revealed to Twain, consciously or unconsciously, his disturbing issues of selfhood and fatherhood which thus made inevitable the ultimate emptying of the closing chapters. In addition, this relationship between Twain and the 
writing of his text is itself a subject of the images and tropes of Huck's early adventures; as the opening chapters turn on struggles with the father, they form, at the same time, a self-conscious commentary on how those struggles come into narrative being.

Implicit in such an explanation of the novel's structure is a psychodynamic model of the creative process which assumes that as authors free associate characters and endings, they gain momentary glimpses of the unconscious issues represented in their fiction. Since authors are always readers of their emerging text, they are continuously faced with the choice of pursuing unconscious feelings and memories evoked by the actions and experience of their characters or of moving onto "safer" narrative ground by choosing to avoid the emotionallyladen material. (They can do this by writing something psychologically neutral, and thus often uninteresting, or through the more neurotic compromise of the writing block.) I refer to analysis of this process as "psychoformalism" because it proposes that a literary work is itself a record of the dialogic relationship between writer and text - between psyche and form. ${ }^{2}$

When Huckleberry Finn first addresses the readers in his beguiling and provocative opening paragraph, he immediately confounds their understanding of who he is. By saying he has read The Adventures of Tom Sawyer and has an opinion about its worth, Finn suggests there is a fictional Huck who should not be confused with the real one. In fact, he strongly implies that the fictional Huck is irrelevant.

2 Although "psychoformalism" is not an established term, the process to which it refers was first noted by Kenneth Burke who presented a technique he called "metaphorical psycho-analysis" along with an all-too-brief reading of Coleridge's pattern of images which served as an example, in The Philosopby of Literary Form: Studies in Symbolic Action (New York: Vintage Books, 1957), 62-76. See also his brilliant essay "Psychology and Form" in Counterstatement (Los Altos: Hermes, 1953). Other related theories include Ernst Kris' classic work on creativity and ego regression, Psychoanalytic Explorations in Art (New York: Shocken Books, 1964); Walter A. Davis' recent exposition of a "hermeneutics of engagement" in Inwardness and Existence: Subjectivity in/and Hegel, Heidegger, Marx and Freud (Madison: University of Wisconsin Press, 1989) could be applied to an author's dialectical relationship with his works; and the undercited work of Albert Rothenberg who argues that creativity is essentially the mechanism of dreamwork in reverse - see his The Emerging Goddess: The Creative Process in Art, Science or Other Fields (Chicago: Univ. of Chicago Press, 1979). A more extensive presentation of the psychoformal approach is in preparation; see also Harry G. Segal, Mark Twain and the Power of the Paternal: A Psychoformal Analysis, unpublished dissertation, English Department, Yale University, 1990, pp 6-64, and Harry G. Segal, The Effort After Meaning : Theoretical, Clinical, and Empirical Justifications for the Psychological Assessment of Narrative, unpublished dissertation, Psychology Department, University of Michigan, 1990. 
You don't know about me, without you have read a book by the name of "The Adventures of Tom Sawyer," but that ain't no matter. ${ }^{3}$ (p. I).

This opening sentence may be read in two ways. It says that it doesn't matter if we have heard of Huck through Tom Sawyer or, taken literally, that Tom Sawyer doesn't matter. In either case, Finn's position on the other novel could not be more clear: knowing The Adventures of Tom Sawyer is not a prerequisite for reading The Adventures of Huckleberry Finn.

The emergence of Huck Finn the narrator has long been of interest to critics. Henry Nash Smith argued that the vernacular first person inadvertently led 'Twain to the creation of a tragic character, while Alan Trachtenberg believes that Huck is trapped by his author's need to use him as a comical figure. ${ }^{4}$ Trachtenberg compares Huck's enslavement to Twain's satiric intentions with Jim's search for political freedom and insists that the novel's attack on society required that Huck remain undeveloped. "Huck's character is stunted by his creator's need for him to serve as a technical device. The same devices of irony which liberate the reader by instructing him about civilization and human nature also repress Huck by using him" (p. 969). The opposed readings of Trachtenberg and Smith form, paradoxically, a continuum of discontinuity; namely, that Huck does "deepen" as a tragic character in the novel's opening and is indeed transformed into a "technical device" long before the ending of the novel. ${ }^{5}$ I propose that Huck's inconsistent voice, at times deeply

${ }^{3}$ Mark Twain, The Adventures of Huckleberry Finn, Tom Sawyer's Comrade (Berkeley: The University of California press edition, 1985).

4 Henry Nash Smith, Mark Twain: The Development of a Writer (Cambridge: Harvard University Press, 1962); Alan Trachtenberg, "The Form of Freedom in Adventures of Huckleberry Finn," Southern Review, 6, (1970) 954-71.

5 More recently, Andrew Jay Hoffman, Twain's Heroes, Twain's Worlds (Philadelphia: University of Pennsylvania Press, 1988) claims that it is a "fruitless" critical task to separate Twain from Huck. "The character we identify as our hero cannot be fully separated from the character who writes him; the writing Huck cannot be fully separated from Mark Twain; the reader cannot be fully separated from the book." (3 r). Hoffman identifies the shifting tone and diction of the novel, decides that this quality necessitates a "holistic" reading, and insists that interpretations will falter if they privilege "only one of the several clearly interdependent parts of the novel" (p. 39). Certainly the contrast of Smith and Trachtenberg's individually influential readings would tend to support Hoffman's caution; Huck both "deepens" as a tragic character, yet seems trapped by the satiric frame surrounding him. However, Hoffman's solution is to step back from the novel and see it as an interplay of history, heroism, and textuality. (For him, Huck is a traditional Raglanian hero who is ultimately powerless at the novel's end because he has been taken from mythology and placed in a "realistic" novel determined by society and the writing of history.) His approach is an interesting 
"autonomous" while at others mechanical and contrived, has to do with his role as narrator-heir to Mark Twain. By turning the fictional Huck into a fictionally "real" person who has read Tom Sawyer and hopes to improve on its quality, Twain unconsciously evoked the struggle between father and son which dominates the tropes and language of the novel's opening. Consider Huck's critique of Tom Sawyer:

That book was made by Mr. Mark Twain, and he told the truth, mainly. There was things which he stretched, but mainly he told the truth. That is nothing. I never seen anybody but lied, one time or another, without it was Aunt Polly Tom's Aunt Polly, she is - and Mary, and the Widow Douglas, is all told about in that book - which is mostly a true book; with some stretchers, as I said before. (p. I).

It is a powerful comma which separates "he told the truth" and "mainly" in the first sentence, for its pause implies that Twain is a liar. Finn may not condemn the famous author openly, but his contempt is never far from the surface. He forgives Twain by saying, "I never seen anybody but lied, one time or another," yet he twice makes it clear that Twain lied often in his narrative: there were "things which he stretched." It was "mostly a true book ... with some stretchers." This opening offers a stark contrast to Tom Sawyer. That novel began with an idyllic portrait of the Missouri town told by a benevolent narrator; Finn begins his book by attacking an established author.

This playful competition between Finn and Twain contains an unconscious rivalry between father and son - a rivalry implicit in Huck's attempt to write a sequel. One of the most problematic of artistic challenges, the sequel is a paradox because of the inherent demands on its form. A sequel must share some of the qualities of the first work without repeating them, extend the first work without violating its premises, and it must be good or better. In this way, the sequel is an escalation of the usual struggle for rhetorical identity-instead of evolving from an established genre while retaining some of its features as all first texts do, the sequel has a specific antecedent for which it must be simultaneously "self" and "other." This can be seen in the opening stance of Huckleberry Finn. A character born in work one (self) now introduces work two (other) and insists that work one is irrelevant. Even the vocabulary of

extension of Robert Regan's work, but it effectively sidesteps the blurring of Twain and Huck by simply pointing out that it exists. He does not attempt to explain why it is so, nor does he address the psychological factors which may have compelled such confusion. 
those first two paragraphs points to the rhetorical dilemma. Finn says that Twain told the truth "mainly," except for some "stretchers." The question is which text is the "main one," and how can an author "stretch" it into a sequel?

Harold Bloom believes every creative act to be a battle between ambitious son-poets and canonical father-texts, yet there is an even closer relation between the writing of a sequel and oedipal phase anxiety. ${ }^{6} \mathrm{~A}$ "strong" poet, according to Bloom, misreads earlier poems so as to achieve difference; an author writing a sequel must achieve differences and resemblance. Psychoanalytic accounts of adolescent development may be of use here. ${ }^{7}$ The children who accommodate oedipal phase anxiety most successfully emerge neither as copies of their same-sex parents nor as opposite versions of them; instead, they enjoy resembling the parent in some ways while taking pride in the strengths which are theirs alone. This erewhonian version of the healthy oedipal child, found primarily in textbooks, encompasses the broadest definition of the word success. For such a child, the values and talents of her parents are not the only qualities she internalizes - her success may resemble her family's, but it will reflect her own culmination of insight and experience. This paradox of originality - that something is original because it treats inherited material in an original way - is reflected in the paradoxical meanings of success. Derived from the Latin sequor, to follow, success literally means something that succeeds something else, while our contemporary understanding of success implies if not an original event, at least one that is self-sufficient and enduring. The essence of the oedipal struggle dwells in these opposed meanings, for the successful child is always a successor. Since sequel is derived from sequor, it signifies a form where the dialectical meanings of success are equally immanent. To succeed is to follow; to follow a successful work with another is to write a sequel.

Since it is an expression of both meanings of success, the sequel is always about the oedipal struggle. Or put another way, sequels are always about being a sequel. To consider some examples, Antony and Cleopatra is a

"After beginning his career by applying the mystical "I/thou" formulations of Martin Buber to romantic poetry, Bloom then embarked on his long and sometimes obscure project of positing a theory of literary succession and influence. See, of course, The Anxiety of Influence (London: Oxford University Press, 1975) and The Map of Misreading (New York: Oxford University Press, 1980).

7 See Anna Freud's major work, The Ego and Mechanisms of Defense (New York: International Universities Press, 1946) as well as that of Peter Blos On Adolescence: $A$ Psychoanalytic Interpretation (New York: Free Press, 1962) - both classic treatises on the successful and unsuccessful outcome of the oedipal phase as first experienced by toddlers and re-evoked during adolescence. 
sequel to Julius Caesar and one of its principal themes is Antony's role, inherited from his "father" Caesar, of being Cleopatra's lover. In the second volume of Don Quixote, Cervantes' knight is no longer the foolish son struggling to join the long lost world of his chivalric fathers but has gained, instead, an obsolete dignity and even, at times, paternal wisdom. ${ }^{8}$ (It is also, wonderfully, an attack on the false sequels published after his brilliant first novel.) The Odyssey begins with the plight of Telemachus and his need to protect his mother from suitors who carry the projections of his own desires. And perhaps the most dramatic example is the New Testament which, as an appendix to the Old Testament, describes Christ's oedipal relationship with God - Jesus, both Son and Father, embodies the Hebrew laws yet irrevocably changes them. So Finn's opening attack on Mark Twain should not be a surprise; it is an inspired announcement that a sequel has begun. ${ }^{9}$

The tension between first text and sequel, Huck Finn and Mark Twain, is nowhere more clear than in the content of Huck's accusation: he calls Mark Twain a liar. By doing so, he implies that his novel will be true while the last novel was false - yet his readers soon learn that Huckleberry Finn is perhaps the most accomplished liar in American literature. This is an evocative contradiction. The accusation suggests that this book will correct Tom Sawyer and reveal those characters as they truly are. However, the ironic narrator who claims to tell the truth while admitting that he tells falsehoods complicates his relationship with the reader. Like Iago who lies to the audience in his asides, Finn's compromised reliability leaves his text open to post-structuralist inquiries: are there fictional truths? are there truthful fictions? Finally, the taste for lying which Huck shares with Twain also returns us to the nature of the sequel, for here the son actively denies his obvious resemblance to the father.

A sequel is ultimately a response, and not an initial statement, if only by virtue of its successor status. If a first novel is defensively optimistic and happy, a place where mothers adopt stray boys and ideal fathers make them their proteges, then one can expect a second novel featuring the same landscape to undo those defenses in the services of difference - it may even present a world without kind mothers, where ideal fathers are powerless. While this paradigm is necessarily reductive, it provides a way

8 See Rene Girard's perceptive argument on the roles of triangulation and desire in Don Quixote in Deceit, Desire and the Novel (Baltimore: Johns Hopkins University Press, I965.)

9 What makes Finn's novel rare, however, is that it is an especially strong sequel. Like the New Testament, read by more people than the Old Testament, The Adventures of Huckleberry Finn is no longer a sequel. For most readers, it is the first text. 
into Huckleberry Finn. To start this search for difference, the St. Petersburg of Huck's novel is not the same one found in The Adventures of Tom Sawyer. The ultimately benevolent town in the first novel, conveyed through literary cliches, has been replaced by a less cohesive, less protective one. Its citizens may bear the same names, but they and their society are different. The saviour-mother of the first book, the Widow Douglas, is now a neglectful woman who grumbles over her meals and gives charge of Huckleberry over to her insensitive sister, Miss Watson. Tom Sawyer, who showed only moments of arrogance in the earlier text, is now openly contemptuous of Huck's "ignorance" and calls him a "numskull." These changes prove false the suggestion implicit in the ending of Tom Sawyer that society would save Huck. This St. Petersburg is not the nostalgic vision of the sleepy, antebellum South capable of rescuing the child in its readers; it is instead a sinister place where violence and isolation are ever present.

I set down in a chair by the window and tried to think of something cheerful, but it warn't no use. I felt so lonesome I most wished I was dead. The stars was shining, and the leaves rustled in the woods ever so mournful; and I heard an owl, away off, who-whooing about somebody that was dead, and a whippowill and a dog crying about somebody that was going to die; and the wind was trying to whisper something to me and I couldn't make out what it was... Then away out in the woods I heard that kind of a sound that a ghost makes when it wants to tell about something that's on its mind and can't make itself understood, and so can't rest easy in the grave and has to go about that way every night grieving. (p. 4)

This oft-quoted passage is the novel's first chapters in miniature, for it captures Huck's surreal isolation. Like moments in an unsettling dream, the boy hears vague messages of death but cannot answer back. Huck is, here and throughout, a witness to loss, and his testimony of the night casts his readers as fellow witnesses. For just as Huck cannot answer the ghost who "can't make itself understood," neither can we, locked on our side of the text, answer Huck.

Not only is the tone and location of this sequel different from its first text, it has a new psychological focus. In Tom Sawyer, Huckleberry Finn escorts Tom to nocturnal landscapes where father corpses are buried and exhumed, and where digging underground leads momentarily to unconscious wishes and fears. Those excursions were a side effect of Tom's gathering success: growing more powerful meant occasional confrontations with his urge to beat the father and his fear of paternal reprisal. In this work, the nocturnal landscape and confrontation with 
fathers are primary events; they overwhelm and dominate the daylit world. Thus, an understanding of the nature of the sequel reveals the psychoformal pressures on The Adventures of Huckleberry Finn, Tom Sawyer's Comrade. As a sequel, it must be about oedipal struggle; as a sequel to Tom Sawyer, a work which moved away from unconscious issues, this novel must move towards them; specifically, Huck must face that father in the graveyard from whom Tom Sawyer escaped to the idealized figure of Judge Thatcher. While these reversals have enormous consequences, their aggregate effect is this : since Huck Finn held back the world of the unconscious in Tom Sawyer, his sequel will dwell there. ${ }^{10}$

The unconscious of the novel is nowhere more apparent than when Huck first mentions his biological father. Ironically (or perhaps predictably), this first news of pap is an exaggerated account of his death, and yet pap's effect on his son and on the text is so powerful that even a false report about him intensifies the mood and structure of the early chapters.

Well, about this time he was found in the river drowned, about twelve mile above town... They judged it was him, anyway; said this drowned man was just his size and was ragged, and had uncommon long hair - which was all like pap - but they couldn't make nothing out of the face at all. They said he was floating on his back in the water. They took him and buried him on the bank. But I warn't comfortable for long, because I happened to think of something. I knowed mighty well that a drownded man won't float on his back, but on his face. So I knowed, then, that this warn't pap, but a woman dressed up in a man's clothes. (p. I4)

An analysis of this passage reveals pap's tremendous impact, for Huck's explanation raises more questions than it answers. If the floating corpse was a woman, why didn't anyone say so? Why does Huck so calmly present his theory without wondering why a woman would be dressed in man's clothes? But Huck's speculation is most intriguing, however, because it foreshadows his return trip to St. Petersburg dressed as a girl in a dress which he and Jim find next to the dead body of pap. This circling of the future into the present, as well as a face that cannot be recognized and a father who may be a woman, evoke the consciousness of dreaming where events and qualities are layered with echoes of

10 To translate this idea into psychoanalytic terms, one could think of Huck Finn as the latent meaning of the manifest content of Tom Sawyer. See also Wayne Fields, "When the Fences are Down; Language and Order in The Adventures of Tom Sawyer and Huckleberry Finn," Journal of American Studies, 24 (1990), 3, 369-386, who argues that the world of Tom is one characterized by order and limits, while in Huck's narrative order is consistently undermined. 
alternate events and qualities. When critics have described Tom Sawyer as a dream of boyhood, they mean literary dreaminess - a nostalgic idealized landscape descended from Romance. True to the nature of the sequel which must be similar and different from its first text, the landscape of Huckleberry Finn is dreamlike in another way: it resembles psychological dreams where identity, impulse and action are neither fixed nor separate. ${ }^{11}$

The false report of pap's death may be a good example of a passage informed by dream logic (or primary process thinking), but it is one of a limited number. The dreamscape is an unstable part of this novel, one clearly difficult to sustain. While the last chapters of Huckleberry Finn fail because of the utter lack of unconscious depth so present in the beginning chapters, even the dreamscape of the novel's opening ebbs and flows like an unconscious tide, drawn, to fulfill the simile, by the waxing and waning of Huck's father. This tentative yet repercussive interchange between the novel's reality and its psychological issues may best be understood by analyzing the sequence of events following the first signs of pap's return.

There was an inch of snow on the ground, and I seen somebody's tracks. They had come up from the quarry and stood around the stile a while, and then went on around the garden fence. It was funny they hadn't come in, after standing around so. I couldn't make it out. It was very curious, somehow. I didn't notice anything at first, but next I did. There was a cross in the left boot-heel with big nails, to keep off the devil. (p. 19)

By not sharing with the reader until several scenes later what that cross in the left boot heel meant - namely, that the tracks belong to his father Huck's description adds suspense to the narrative. Aside from piquing the reader's interest, omitting the name of the early morning stalker also blurs his identity and allows his tracks to evoke a host of possibilities. Consider the second sentence: "they had come up from the quarry..." Huck's persistent use of the third person plural only emphasizes the multiple referents of the pronoun. It suggests that there are many fathers who could be circling his house, and in a narrative where Huck adopts a series of men to father him, his use of "they" takes on a proleptic quality. Besides foreshadowing events in the narrative, this passage also harkens

11 A beautiful description of this kind of awareness may be found in an early chapter of The Magic Mountain. As his grandfather once again shows Hans Castorp the family's baptismal bowl and recounts the young boy's christening, "a familiar feeling pervaded the child: a strange, dreamy, troubling sense: of change in the midst of duration, of time as both flowing and persisting, of recurrence in continuity - these were sensations he had felt before on the like occasion, and both expected and longed for again, whenever the heirloom was displayed." Thomas Mann, The Magic Mountain, trans. H. T. Lowe-Porter (New York: Knopf, 1949), 23. 
back to the false report of pap's death. That "they" have come "up from the quarry" sounds as though people have come up from underground or up from the grave, while the crossing of the fence suggests a return from the underworld. Within the passage, therefore, the wish that his father were dead is combined with the wish that he return.

Huck immediately responds to the sighting of his father's footprints by rushing to Judge Thatcher, the ideal father of Tom Sawyer, for help. In an exchange noted by one critic for its ambiguous treatment of Thatcher, Huck tries to give him his money. ${ }^{12}$

\section{He says:}

"Well I'm puzzled. Is something the matter?"

"Please take it," says I, "and don't ask me nothing - then I won't have to tell no lies."

He studied a while, and then he says:

"Oho-o. I think I see. You want to sell all your property to me - not give it. That's the correct idea."

Then he wrote something on a piece of paper and read it over and says:

"There - you see it says 'for a consideration.' That means I have bought it of you and paid you for it. Here's a dollar for you. Now you sign it." (pp. 19-20) A close look at this scene shows that Huck has not come to the Judge for help. Quite to the contrary, instead of telling him what happened Huck remains silent and insists that Thatcher take his gold. Although Huck never tells the reader why he does this, one plausible explanation is that he wishes to keep the money and assumes that his father will have a more difficult time getting it away from an adult than from a child. If so, by using him as an obstacle the boy has set up the Judge as effectively as any professional con man. And while his entrapment of Thatcher may seem unwarranted, the Judge's reaction appears to justify Huck's expectations of him. Like all good cons, success depends upon the greed of the mark. Although he returns Huck's money at the end of the novel, there is no suggestion in the present passage that Thatcher intends to do so. "He studied a while," Huck writes, and then says "Oho-o... You want to sell all your property to me... not give it." The King or the Duke would have been worthy of 'studying' for a moment before coming up with a

12 Robert Regan, in his excellent book on Mark Twain, is the only critic I have found who questions the integrity of Judge Thatcher in this scene. Regan sees a "hint" of hypocrisy in Thatcher even in Tom Sawyer and argues that the Judge's redemptive act of returning Huck's money at the end of the novel takes place "several years and several hundred pages after the scene in which [he] gives Huck a dollar in return for his fortune." He goes on to speculate: "Perhaps the author had simply forgot the seed of doubt about the Judge's honesty he had planted so long before." Robert Regan, Unpromising Heroes (Berkeley: University of California Press, 1966), 135. 
discrimination as sophistical as that between giving away cash and selling it for a dollar ("That's the correct idea"). From a man looked up to as a god by the townspeople in Tom Sawyer to a lawyer contemplating taking money from a child in Huckleberry Finn, Thatcher sounds like a con man, too. In this sequel, ideal fathers are no longer ideal.

Huck's encounter with paternal figures does not stop with the Judge, for in the very next scene he seeks out a third and more welcoming father: he goes to Jim with the hope that Jim's hairball, "taken from the fourth stomach of an ox," might tell him something about pap. After trying to get it to roll on the floor, Jim announces that the hairball "sometimes wouldn't talk without money."

I told him I had an old slick counterfeit quarter that warn't no good because the brass showed through the silver a little, and it wouldn't pass nohow, even if the brass didn't show, because it was so slick it felt greasy and so that it would tell on it every time. (I reckoned I wouldn't say nothing about the dollar I got from the judge.) I said it was pretty bad money, but maybe the hairball would take it, because maybe it wouldn't know the difference. Jim smelt it, and bit it, and rubbed it, and said he would manage so the hairball would think it was good. $\mathrm{He}$ said he would split open a raw Irish potato and stick the quarter in between and keep it there all night, and next morning you couldn't see no brass, and it wouldn't feel greasy no more, and so anybody in town would take it in a minute, let alone a hairball. (p. 2I)

In its structure this scene is, literally, a new version of Huck's exchange with Judge Thatcher, but one sporting several important changes. In both instances the boy has gone to an older man for help and the man has charged him for services rendered. Yet in the second version, man and boy have found more trustworthy partners. Huck apparently feels comfortable enough to confide in Jim the signs of pap's imminent arrival, just as Jim generously lowers his price and accepts the false quarter for payment. (Of course, the exchange is not without an undertone of struggle: Jim still claims the hairball needs money, while Huck "reckoned" he wouldn't say anything about the dollar given him by the Judge.)

As a new version of the Thatcher meeting, Huck's scene with Jim serves as a reading of the earlier one. The central image of the "old counterfeit quarter that warn't no good" may be understood as representing the "counterfeit" transaction with the Judge (and by metonymy the coming relationship with pap). As the better father, Jim's remedy for the brass quarter is both magical and suggestive: the "raw Irish potato" will be "split open," and the quarter placed between the 
two halves and kept there "all night." This process, a kind of Missouri alchemy, strongly implies that father relationships, so fraught with fear and loathing, can be changed into something of value. That is, a more peaceful intimacy - such as floating down the Mississippi on a raft - may transform something "counterfeit" and violent into something real. Such a transformation needs a magic spell or, to decode the metaphor, it requires the unique range of literary form which can contain and generate a progressively redemptive series of fathers.

Still, solving the problem of the bad father is not as simple as merely moving from pap to Thatcher to Jim. If the "cure" for the quarter is examined more closely, it seems to cause as many problems as it is meant to solve. The potato is cut into two pieces and then put back together, suggesting a primitive scheme of identity where self and other are aspects of each other, where two selves forming a symbiotic whole are constantly split apart and rejoined. (This neatly predicts Huck's life with pap in the cabin.) It would appear, then, that for this text getting close to a good father is terrifying because it evokes, among other deep memories and wishes, the earlier, violent symbiosis. This explains why the loving relationship between Huck and Jim, forever strained by Huck's social guilt, is continually interrupted by arbitrary twists in the plot as well as by long writing blocks suffered by Mark Twain. Even the magic spell itself betrays the possibility of a real reconciliation with the father because the cure is ultimately cosmetic. After a night between the pieces of potato, the quarter will still be "bad money" - it will only seem genuine.

Since the sighting of the footprints, the meeting with Thatcher, and the conference with Jim are all about the psychological consequences of the father's approach, these scenes may also be read as a commentary on Huck's relationship with Mark Twain. Finn begins his narrative, after all, by challenging Twain, and the nature of the sequel, oedipal in form, makes a compelling case for considering Twain as an aspect of pap.

There was an inch of snow on the ground, and I seen somebody's tracks. They had come up from the quarry and stood around the stile a while, and then went on around the garden fence. It was funny they hadn't come in, after standing around so. I couldn't make it out.

Twain is present in a generalized way through the topology of this passage. It suggests a diagram of the creative process, with the idea or inspiration "coming up" from the imagination only to be shaped by "stile" and narrative limits, represented by the garden fences. (There is even a lingering pun in quarry, considering that Twain 'mined' his 
childhood for his fiction. ${ }^{13}$ ) To bring the creator directly into this metaphor of his writing process, let us assume that it is Twain himself who has come up from the quarry, who has encountered Huck's "stile," and who has circled the house without entering. Although Huck puzzles over why "they" hadn't come in, the answer may not be as mysterious as he thinks. If Twain had come into the house, then Huck would not have remained the narrator of Huckleberry Finn. Instead, the unentered house represents the "otherness" of the narrative, while its closed doors emphasize the distance between fiction and its author. The tracks in the snow, which showed that the man "stood around" for a long time, foreshadow the long eight years Twain will struggle to finish this disturbing narrative that he often tried to "pigeonhole" and once threatened to burn. The tracks show him circling his house of fiction and seeing within alien figurations which had emerged, somehow, from the dark passages of his quarry.

This circling of Huck by Twain, representing the inherent struggle of writing a sequel, is also figured within Jim's alchemical treatment of Huck's counterfeit quarter. This "bad money" that "wouldn't pass nohow ... because it was so slick it felt greasy and so that it would tell on it every time" stands for the dubious second text that must somehow pass for the original. Compromised by a first text written in an irretrievable confluence of imagination and recollection, and which may now seem foreign to him despite its faintly familiar strength, the author must coin a new text in the image of the older one. Cutting the potato in two symbolizes Twain's solution: there will be a second narrator, and a set of fathers to replace Judge Thatcher, and a new story that will, at least in its opening chapters, reveal the depths of unconscious feelings merely hinted at in the dark underground moments of Tom Sawyer. Keep that quarter "there all night," after a night of dreaming perhaps, and "anybody in town would take it in a minute."

The psychological price exacted for launching an alter ego narrator who claims, as textual material, narrative ground repressed in your first novel, is the rich but unsettled disorganization of poorly defended feelings so vividly represented by the floating female body of pap and his subsequent resurrection. As the historic controversy over the Phelps Farm escape sequence suggests, the unconscious depth claimed by the new

13 I am grateful to John Seeleye for his comments as a reviewer on this manuscript. He suggests that the pun on quarry may be a triple pun: "Twain wrote much of Huck Finn while staying at Quarry Farm near Elmira - a place he associated with creativity." I am also grateful for the comments of Eric Sundquist, another reviewer. 
author, Huck Finn, is only sustained until the old author, threatened finally by the reflection of his own aggression and longing for the father, hastens to restore to his novel the parodies, satires, and other literary devices which served him so well as a journalist and which ultimately take from Huckleberry Finn the temporary majesty of its opening chapters. The ending represents a desperate attempt to return to The Adventures of Tom Sawyer, to evade feelings conjured by the writing of its sequel; the claustrophobic quality and emotional vacancy of the Phelps Farm escape sequence suggests Twain succeeded in making his own escape.

After leaving Jim's consultation with the hairball, Huck walks home only to find his father waiting in his bedroom. It is not long after that pap wins custody of him, sues Thatcher for the money, and takes Huck away to a small cabin where he regularly beats him. The description of life in that cabin is perhaps the most powerful and dreamlike scene in the novel because it is the final and most prolonged encounter between son and father. Yet as we have seen, before it happens the tropes, images and events of the narrative seem preoccupied with it; it is as if the time with pap in the cabin left a proleptic impression on the narrative leading up to it. The coming relationship with pap exerts this influence because life without father is impossible for Huckleberry Finn; both Huck and his narrative are constituted by the race from and inevitable attraction to the paternal. This may be glimpsed nowhere more keenly than in this last look at Huck's discovering of his father's footprints:

I didn't notice anything at first, but next I did. There was a cross in the left bootheel with big nails, to keep off the devil.

The novel's collision of form and psychological force is so monolithic that its repercussions threaten to break the very frame of the text - for the cross placed in pap's left boot-heel, designed to "keep off the devil," shows that even the father of the narrative is running from a father. 